\title{
Oxidation of Fatty Acids in Cultured Fibroblasts: a Model System for the Detection and Study of Defects in Oxidation
}

\author{
JEAN-MARIE SAUDUBRAY, ${ }^{(38)}$ FRANÇOIS-XAVIER COUDÉ, FRANCE DEMAUGRE, \\ CHARLES JOHNSON, KENNETH M. GIBSON, AND WILLIAM L. NYHAN \\ Clinique et Unité de Recherche de Génétique Médicale (INSERM U12) Département de Pédiatrie, Hôpital des \\ Enfants Malades, Paris, France and Department of Pediatrics, University of California San Diego, La \\ Jolla, California, USA
}

\begin{abstract}
Summary
A number of recently described inherited disorders interfere with the oxidation of fatty acids. In these disorders at least three different metabolic steps may be affected: (1) transport of long chain fatty acids into the mitochondria as in carnitine deficiency and carnitine palmitoyl transferase deficiency (CPT); (2) multiple acyl $\mathrm{CoA}$ dehydrogenase deficiency or glutaric aciduria type II (GAII) due presumably to a defective common electron transfering flavoprotein or iron sulfur flavoprotein; (3) specific long or medium chain fatty acyl CoA dehydrogenase deficiency as in inherited dicarboxylic aciduria. In order to develop a system for the detection and the study of the consequences of defects such as these on the oxidation of fatty acids, we investigated the metabolism of oleate (18 carbons), octanoate (eight carbons) and butyrate (four carbons) in intact cultured fibroblasts from patients with CPT deficiency, GAII, and dicarboxylic aciduria.

In CPT deficient cells there was a markedly deficient ability to oxidize $\left[1-{ }^{14} \mathrm{C}\right]$ and $\left[\mathrm{U}-{ }^{14} \mathrm{C}\right]$ oleate $(19$ and $5 \%$ of normal, respectively), whereas oxidations of $\left[1-{ }^{14} \mathrm{C}\right]$ octanoate and $\left[1,4^{14} \mathrm{C}\right]$ succinate were significantly increased (150 and $222 \%$, respectively), and $\left[1-{ }^{14} \mathrm{C}\right]$ butyrate oxidation was normal. GAII cells displayed a nearly complete defect in the oxidation of $\left[1-{ }^{14} \mathrm{C}\right]$ and $\left|\mathrm{U}^{14} \mathrm{C}\right|$ oleate (8 and $1 \%$, respectively), as well as of $\left[1-{ }^{14} \mathrm{C} \mid\right.$ octanoate and $\left[1-{ }^{14} \mathrm{C}\right]$ butyrate (8 and $5 \%$ of normal, respectively). The oxidation of $\left[1,4^{14} \mathrm{C}\right]$ succinate by GAII cells was normal. Cells from a patient with dicarboxylic aciduria showed a significant reduction in $\left[{ }^{14} \mathrm{CO}_{2}\right]$ production from $\left[\mathrm{U}^{14} \mathrm{C}\right]$ oleate $(57 \%)$ and $\left[1-{ }^{14} \mathrm{C}\right]$ octanoate $(31 \%)$ and a normal oxidation of $\left[1-{ }^{14} \mathrm{C}\right]$ oleate, $\left[1-{ }^{14} \mathrm{C}\right]$ butyrate, and $\left[1,4-{ }^{14} \mathrm{C}\right]$ succinate. These observations are consistent with available information on the normal metabolism of fatty acids in liver and muscle and also with the hypothesis about the molecular localization of the defects in GAII and inherited dicarboxylic aciduria. They demonstrate that intact cultured skin fibroblasts represent a reliable and convenient model for the investigation of fatty acid oxidation in man.
\end{abstract}

\section{Speculation}

Many aspects of the human acyl CoA dehydrogenases and their physiologic functions remain unknown, among them the problem of their acyl chain length specificity. Studies in cultured fibroblasts from patients with presumed mutations affecting the metabolism of fatty acids provide a means for the elucidation of these defects and at the same time give information on normal metabolic functions. It appears likely that a number of previously unrecognized defects in this area of metabolism remain to be found. The availability of a model system for their study in cultured fibroblasts should facilitate their discovery.
The oxidation of fatty acids plays a major role in energy metabolism. In peripheral tissues it provides the main source of energy during fasting. In the liver it results in production of ketone bodies and increases gluconeogenic flux by providing the acetyl $\mathrm{CoA}$ and the reducing equivalents (NADH) necessary for gluconeogenesis (24). Several disorders of metabolism, both acquired and inherited, have been described in which there is defective oxidation of fatty acids. These defects occur at a number of key steps. The first is that of defective transport of long chain fatty acids into the mitochondria, as occurs in generalized $(7,9)$ or muscular $(9,12)$ carnitine deficiency, or muscular (1) or hepatic carnitine palmitoyl transferase deficiency (CPT) (4). The second is a generalized or multiple acyl $\mathrm{CoA}$ dehydrogenase deficiency which may be due to a defect in a common electron transferring flavoprotein (ETF) (18) or ETF dehydrogenase (33) as the case may be in ethylmalonic adipic aciduria (22) or glutaric aciduria type II (GAII) $(11,31)$, or secondary to the action of a toxic agent such as hypoglycin A in Jamaican vomiting sickness (35). The third step is that of a possibly specific medium or long chain fatty acid dehydrogenase deficiency (26) as may be the case in so-called dicarboxylic aciduria (14).

The clinical presentation in these different situations is variable. There are chronic courses with myocardiopathy and proximal myopathy and muscular accumulation of lipid droplets. There are intermittent attacks of hepatic encephalopathy with negligible symptoms in between; and fatal acute courses resembling Reye's syndrome. A common but not obligatory feature for all is hypoketotic hypoglycemia with dicarboxylic aciduria which suggests an impairment of $\beta$ oxidation.

In order to study the consequences of these defects on the oxidation of fatty acids we investigated the formation of $\left[{ }^{14} \mathrm{CO}_{2}\right]$ from labeled fatty acids oleate, octanoate, and butyrate using succinate as a control in cultured fibroblasts derived from skin. In order to distinguish among the abnormalities in the transport of long chain fatty acids into the mitochondria and those of the $\beta$ oxidation of long, medium, or short chain fatty acids, we compared the results obtained from cells of patients with carnitine palmitoyl transferase deficiency, glutaric aciduria type II, and dicarboxylic aciduria.

\section{MATERIALS AND METHODS}

Cell culture. Cultured fibroblasts derived from skin were obtained from a previously published patient with a complete deficiency of hepatic carnitine palmitoyl transferase (4), one with severe neonatal glutaric aciduria type II (8), and an unreported patient with congenital dicarboxylic aciduria (gift of P. Divry, Lyon, France). Five control lines were obtained from healthy children aged 1-2 years. The fibroblasts were grown in roller 
bottles in Eagle's minimal essential medium (MEM) (Irvine Scientific Co., Santa Ana, CA), supplemented with $10 \%$ bovine fetal calf serum (FCS), nonessential amino acids and antibiotics (penicillin $100 \mu \mathrm{g} / \mathrm{ml}$, streptomycin $100 \mu \mathrm{g} / \mathrm{ml}$ ). All assays were performed between passages 6 and 9 . Monolayers of fibroblasts on roller bottles were washed with phosphate buffered saline (PBS) and trypsinized when confluent, and the cells were counted. The cells were resuspended in MEM containing $10 \%$ FCS. Between $0.5-0.75 \times 10^{6}$ cells in $3 \mathrm{ml}$ were put in $25 \mathrm{ml}$ plastic tissue culture flasks (Corning Glass Works, Corning, NY) for $18 \mathrm{~h}$ to obtain monolayers for experiments on oxidation. For each experiment two to three control flasks were trypsinized and used to determine cell numbers.

Substrate oxidation by cultured skin fibroblasts. The oxidation of the following five substrates was tested: $\left[1-{ }^{14} \mathrm{C}\right]$-oleic acid, specific activity $57 \mathrm{mCi} / \mathrm{mmol}$; [U- ${ }^{14} \mathrm{C}$-oleic acid, $999 \mathrm{mCi}$ / mmole; $\left[1-{ }^{14} \mathrm{C}\right]$-octanoate (sodium salt), $27.03 \mathrm{mCi} / \mathrm{mmole} ;\left[1-{ }^{14} \mathrm{C}\right]$ -butyrate (sodium salt), $14 \mathrm{mCi} / \mathrm{mmole}$; and $\left[1,4-{ }^{14} \mathrm{C}\right]$-succinic acid, $49.5 \mathrm{mCi} / \mathrm{mmole}$ (New England Nuclear, Boston, MA).

The $\left[1-{ }^{14} \mathrm{C}\right]$ - and $\left[\mathrm{U}-{ }^{14} \mathrm{C}\right]$-oleic acids in hexane solution were dried under nitrogen, dissolved in ethanol, and diluted with nonisotopic sodium oleate (Sigma Lab., St Louis, MO) to obtain approximately $1500 \mathrm{cpm} /$ nanomole. This solution was complexed to fatty acid free Pentex bovine albumin (Miles Laboratories, Elkhart, Ind.) at a ratio of 20 nmole of substrate fatty acid per $\mathrm{mg}$ of albumin and mixed with $100 \mu$ l of delipidated fetal calf serum prepared according to the method of Cham and Knowles (6). [1$\left.{ }^{14} \mathrm{C}\right]$-Octanoate (sodium salt), $\left[1-{ }^{14} \mathrm{C}\right]$-butyrate (södium salt) and $\left[1,4-{ }^{14} \mathrm{C}\right]$-succinic acid in ethanol were diluted with their respective nonisotopic substrates (Sigma Lab., St Louis, MO), to obtain about $1500 \mathrm{cpm} /$ nanomole for octanoate and butyrate, and $200-300 \mathrm{cpm} /$ nanomole for succinate. After $18 \mathrm{~h}$ in culture monolayers of fibroblasts were washed two times with $3 \mathrm{ml}$ of PBS, and $1.5 \mathrm{ml}$ of Leibovitz's medium L-15, pH 7.6 (Irvine Scientific Co., Santa Ana, CA) were put in each flask. This medium contains an arginine phosphate buffer system and does not contain bicarbonate. The reactions were initiated by adding the radioactive mixture to the incubation flasks to yield a final volume of $2 \mathrm{ml}$. The flasks were tightly closed with stoppers (Kontes, CA), and plastic center wells (Kontes, CA) were attached each containing a $3 \times 3 \mathrm{~cm}$ piece of Whatman No. 1 filter paper. The flasks were incubated at $37^{\circ} \mathrm{C}$. At the end of the incubation, $150 \mu \mathrm{l}$ of $1 \mathrm{M}$ hyamine hydroxide (Sigma Lab., St Louis, MO) was injected onto the filter paper and the radioactive $\mathrm{CO}_{2}$ released was collected for $30 \mathrm{~min}$ at room temperature without acidification of the medium. This method gave $85-95 \%$ collection of $\left[{ }^{14} \mathrm{CO}_{2}\right]$ and lower blank values $(<50 \mathrm{cpm})$ as compared to that with acidification, $(50 \mu \mathrm{l}$ of perchloric acid $10 \mathrm{M}$ ). After collection, the flasks were opened and the filter papers were placed in vials containing $10 \mathrm{ml}$ scintillation fluid [0.5\% 2,5 diphenyloxazole (scintillation grade) Packard in $90 \%$ toluene, $10 \%$ ethanol] and counted in a Beckman LS-250 scintillation spectrophotometer.

The oxidation of each radioactive substrate was tested 2-7 times. All of the assays were done in duplicate or triplicate. Statistical significance of differences obtained was assessed using Student's $t$ test.

\section{RESULTS}

In developing the methodology it was first determined that in normal fibroblasts the oxidation of $\left[1-{ }^{14} \mathrm{C}\right]$-oleate to $\left[{ }^{14} \mathrm{CO}_{2}\right]$ proceeded linearly with time and with the number of cells (Figure 1). The saturating concentration of substrate was between $0.2-0.5$ $\mathrm{mM}$ (Figure 2). The same data were obtained for $\left[\mathrm{U}-{ }^{14} \mathrm{C}\right]$-oleate, $\left[1-{ }^{14} \mathrm{C}\right]$-octanoate, $\left[1-{ }^{14} \mathrm{C}\right]$-butyrate and $\left[1,4-{ }^{14} \mathrm{C}\right]$-succinate. On the basis of the data obtained, the experimental conditions used in this study were developed. These are summarized in Table 1. Conditions for the oxidation of each substrate were selected so as to employ saturating concentrations of substrates. The times of
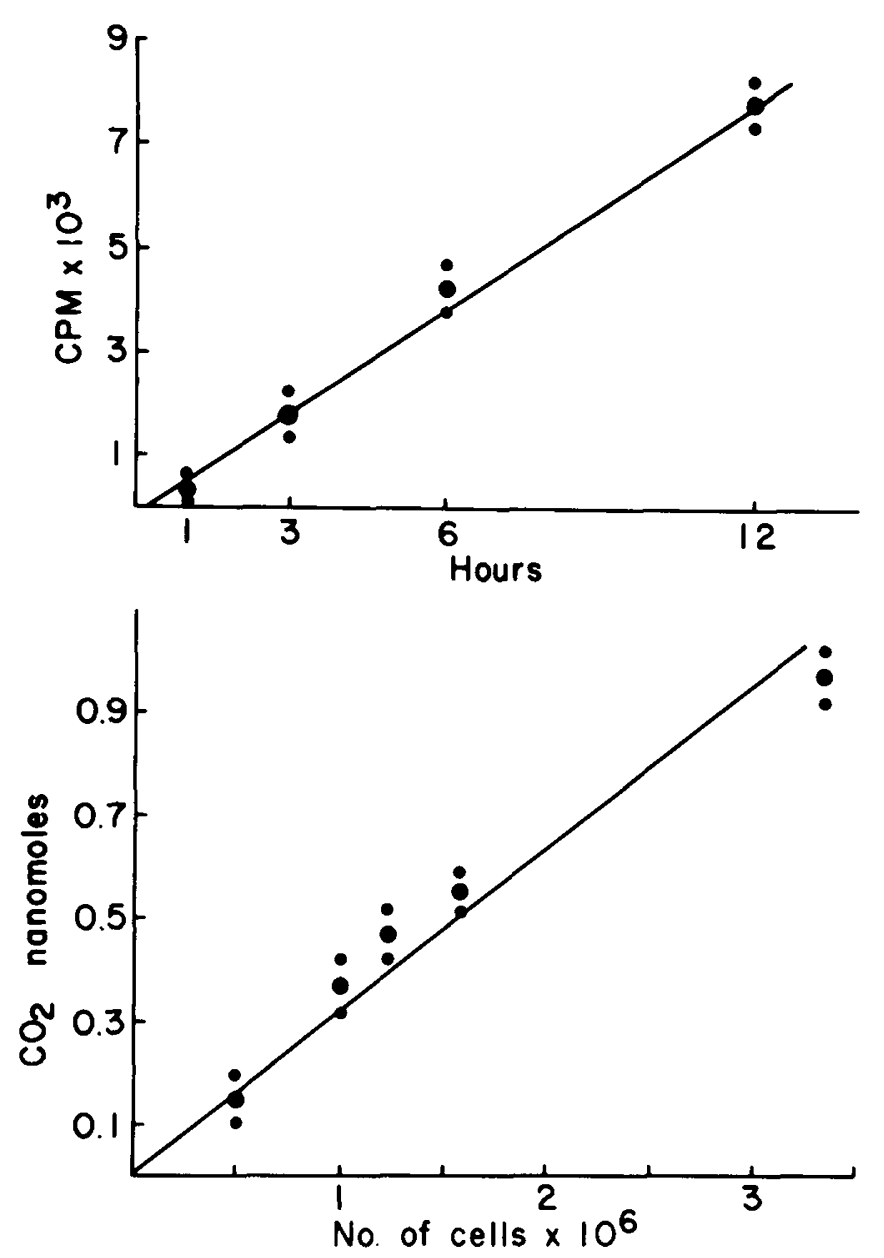

Fig. 1. (Upper panel), Conversion of $\left[1-{ }^{14} \mathrm{C}\right]$-oleate to $\left[{ }^{14} \mathrm{CO}_{2}\right]$ by control fibroblasts. The final concentration of oleate was $5 \mu \mathrm{M}$. The number of cells was $10^{6}$. (Lower panel), Conversion of $\left[1-{ }^{14} \mathrm{C}\right]$-oleate to $\left[{ }^{14} \mathrm{CO}_{2}\right]$ by control fibroblasts. The data plotted were nmoles of released $\mathrm{CO}_{2}$. The final concentration of oleate was $50 \mu \mathrm{M}$. The time of incubation was $6 \mathrm{~h}$. In both panels, each big point represents the mean of duplicate determinations less the value of blanks in which there were no cells. Individual values are symbolized by small points.

incubation were varied to permit the logistics of the experiment and avoid the handling of large numbers of operations at once.

The oxidation of the various experimental substrates to $\left[{ }^{14} \mathrm{CO}_{2}\right]$ in the normal and pathologic cell lines studied are presented in Table 2. In control cell lines there was abundant oxidation of each of the substrates, good agreement among duplicate assays, and a small degree of variation on the same cell line.

Carnitine palmitoyl transferase deficiency. Cells from the patient with carnitine palmitoyl transferase deficiency were assayed on 10 and 8 different occasions for oxidation of $\left[1-{ }^{14} \mathrm{C}\right]$ and $\left[\mathrm{U}-{ }^{14} \mathrm{C}\right]$ oleate, respectively. The mean production of $\left[{ }^{14} \mathrm{CO}_{2}\right]$ from $\left[1-{ }^{14} \mathrm{C}\right]$ -oleate was $19 \%$, and that of $\left[\mathrm{U}-{ }^{14} \mathrm{C}\right]$-oleate $5 \%$ that of the mean of control. These differences were highly significant statistically $(P<0.001)$. By contrast the production of $\left[{ }^{14} \mathrm{CO}_{2}\right]$ measured from $\left[1-{ }^{14} \mathrm{C}\right]$-octanoate and $\left[1,4-{ }^{14} \mathrm{C}\right]$-succinate was significantly increased $(P<0.01)$. These values were $150 \%$ and $222 \%$ of control, respectively.

Glutaric aciduria Type II. In the cells of the patient with glutaric aciduria Type II, the oxidation of each of the substrates except succinate was markedly defective. The mean rates of productions of $\left[{ }^{14} \mathrm{CO}_{2}\right]$ from $\left[1{ }^{14} \mathrm{C}\right]$ and $\left[\mathrm{U}-{ }^{14} \mathrm{C}\right]$-oleate, $\left[1-{ }^{14} \mathrm{C}\right]$-octanoate, and $\left[1-{ }^{14} \mathrm{C}\right]$-butyrate were $8,1,8$ and $5 \%$ of control. These differences were highly significant statistically $(P<0.001) \cdot\left[{ }^{14} \mathrm{CO}_{2}\right]$ Production from succinate was similar to that of the controls. 


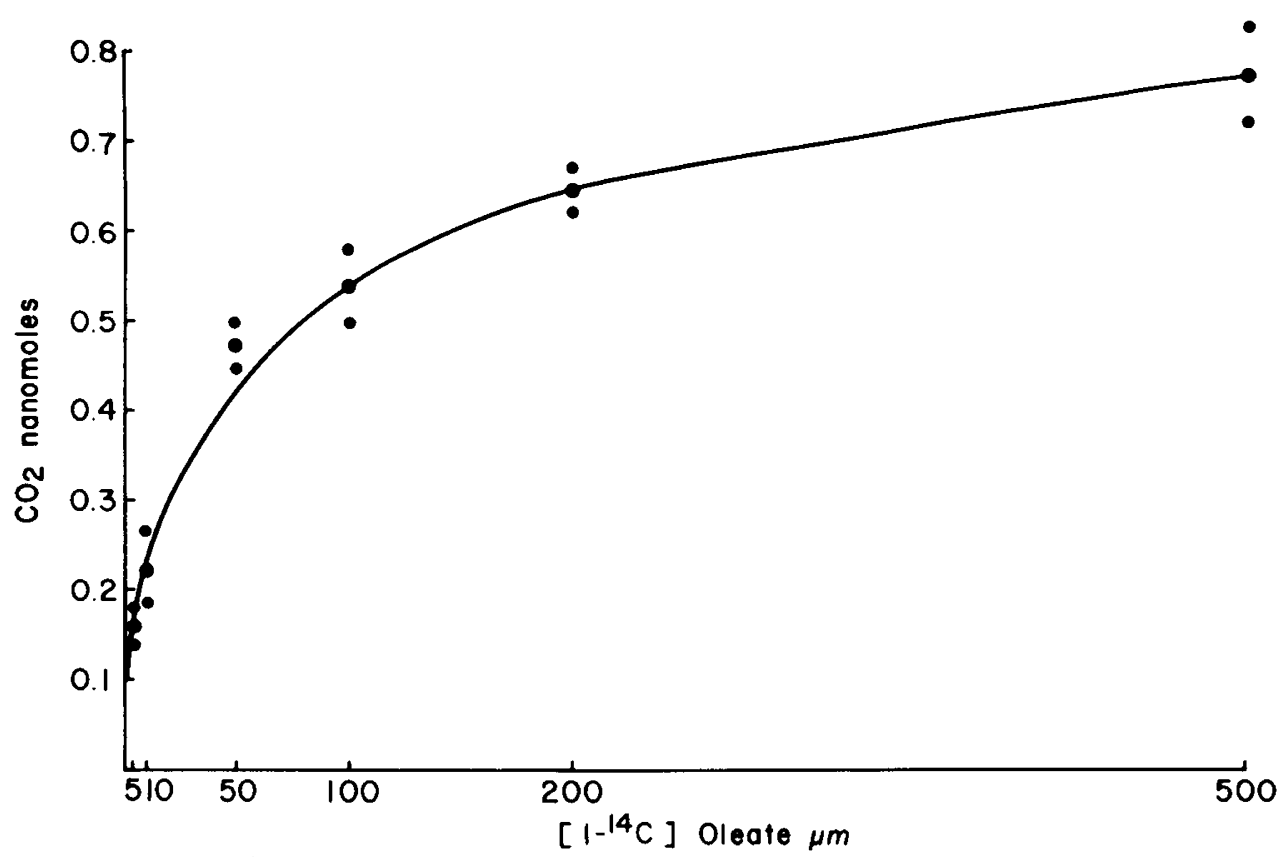

Fig. 2. Conversion of $\left[1-{ }^{14} \mathrm{C}\right]$-oleate to $\left[{ }^{14} \mathrm{CO}_{2}\right]$ by control fibroblasts. The number of cells was $10^{6}$. The time of incubation was $6 \mathrm{~h}$. Each big point represents the mean of duplicate determinations less the value of blanks in which there were no cells. Individual values are symbolized by small points.

Table 1. Experimental conditions

\begin{tabular}{lccccc}
\hline & {$\left[1-{ }^{14} \mathrm{C}\right]$-Oleate } & {$\left[\mathrm{U}-{ }^{14} \mathrm{C}\right]-$ Oleate } & {$\left[1-{ }^{14} \mathrm{C}\right]$-Octanoate } & {$\left[1-{ }^{14} \mathrm{C}\right]-$ Butyrate } & {$\left[1,4-{ }^{14} \mathrm{C}\right]-$ Succinate } \\
\hline Final concentration $(\mathrm{mM})$ & 0.25 & 0.25 & 0.50 & 0.75 & 1 \\
Radioactivity $(\mu \mathrm{Ci})$ & 0.5 & 0.5 & 1 & 5 & 1 \\
Incubation time $(\mathrm{h})$ & 6 & 6 & 5 & 3 & $0.5-0.75$ \\
Number of cells & $0.5-0.75$ & $0.5-0.75$ & $0.5-0.75$ & $0.5-0.75$ \\
\hline
\end{tabular}

'The number of cells represented are those plated at the beginning of the experiment. At incubation $18 \mathrm{~h}$ later the actual numbers of cells were counted, and the data were expressed per $10^{6}$ cells.

Table 2. Oxidation of $\left[1-{ }^{14} \mathrm{C}\right]$-oleate, $\left[U-{ }^{14} \mathrm{C}\right]$-oleate, $\left[1-{ }^{14} \mathrm{C}\right]$-octanoate, $\left[1-{ }^{14} \mathrm{C}\right]$-butyrate, $\left[1,4-{ }^{14} \mathrm{C}\right]$-succinate by cultured skin fibroblasts

Substrates

\begin{tabular}{|c|c|c|}
\hline$\left[1-{ }^{14} \mathrm{C}\right]$-Oleate & $\begin{array}{c}{\left[\mathrm{U}-{ }^{14} \mathrm{C}\right] \text {-Oleate }} \\
\text { nmole }\left[{ }^{14} \mathrm{CO}_{2}\right] \text { produced } / 10^{6} \text { cells/incubation time }\end{array}$ & {$\left[1,4-{ }^{14} \mathrm{C}\right]-$ Succinate } \\
\hline
\end{tabular}

\section{Control 1}

Control 2

Control 3

Control 4

Control 5

Mean of 5 controls

Carnitine palmitoyl transferase deficiency

Glutaric aciduria Type II

Congenital dicarboxylic aciduria

$\begin{array}{cc}0.58 \pm 0.07 & 0.24 \pm 0.04 \\ (10) & (6) \\ 0.72 \pm 0.12 & 0.37 \pm 0.06 \\ (4) & (6) \\ 0.41 \pm 0.02 & 0.27 \pm 0.02 \\ (4) & (4) \\ 0.83 \pm 0.05 & 0.42 \pm 0.03 \\ (8) & (7) \\ 0.95 \pm 0.08 & 0.45 \pm 0.09 \\ (5) & (5) \\ 0.70 \pm 0.09 & 0.35 \pm 0.04 \\ 0.13 \pm 0.03^{3} & 0.02 \pm 0.007^{3} \\ (10) & (8) \\ 0.06 \pm 0.004^{3} & 0.005 \pm 0.0004^{3} \\ (8) & (8) \\ 0.52 \pm 0.05 & 0.20 \pm 0.008^{2,6}\end{array}$

$1.20 \pm 0.13$
$(8)$
$2.03 \pm 0.26$
$(6)$
$1.96 \pm 0.11$
$(6)$
$2.34 \pm 0.23$
$(12)$
$2.00 \pm 0.30$
$(4)$
$1.91 \pm 0.19$
$2.86 \pm 0.15^{2}$
$(10)$
$0.15 \pm 0.01^{3}$
$(10)$
$0.60 \pm 0.06^{3.5}$
$(10)$

$2.79 \pm 0.34$
$(8)$
$4.44 \pm 0.51$
$(6)$
$4.07 \pm 0.33$
$(6)$
$4.28 \pm 0.62$
$(11)$
$6.11 \pm 1.07$
$(7)$
$4.34 \pm 0.53$
$4.77 \pm 0.43$
$(9)$
$0.24 \pm 0.02$
$(10)$
$3.58 \pm 0.36$

(10)
$2.01 \pm 0.26$

$1.76 \pm 0.17$

(6)

$2.95 \pm 0.26$

(14)

$2.25 \pm 0.18$

(4)

$2.08 \pm 0.25$

$4.63 \pm 0.44^{2}$

(10)

$1.74 \pm 0.08$

(8)

$2.44 \pm 0.21$

(14)

\footnotetext{
${ }^{1}$ The data expressed are the means \pm S.E. The number of assays is given in parentheses. The following symbols have been employed: ${ }^{2}$ Significantly different from control $(P<0.01) ;{ }^{3}$ significantly different from control $(P<0.001) ;{ }^{5}$ significantly different from glutaric aciduria type II $(P<0.05)$; and ${ }^{6}$ significantly different from glutaric aciduria type II $(P<0.001)$.
} 
Dicarboxylic aciduria. In the cells of the patient with dicarboxylic aciduria there was a significantly lower rate of $\left[{ }^{14} \mathrm{CO}_{2}\right]$ production from $\left[\mathrm{U}-{ }^{14} \mathrm{C}\right]$-oleate and $\left[1{ }^{14} \mathrm{C}\right]$-octanoate $(P<0.01)$ and $(P<0.001)$. The mean values were $57 \%$ and $31 \%$ of the means of controls, respectively. By contrast, production of $\left[{ }^{14} \mathrm{CO}_{2}\right]$ from $[1,4-$ $\left.{ }^{14} \mathrm{C}\right]$-succinate, $\left[1-{ }^{14} \mathrm{C}\right]$-butyrate and $\left[1-{ }^{14} \mathrm{C}\right]$-oleate was within the normal range.

\section{DISCUSSION}

The studies represent the development of a method for the investigation of fatty acid oxidation in man. A major principle is the use of intact cultured skin fibroblasts undergoing metabolism while still attached. The data obtained indicate that this is a reliable and convenient model and that it is capable of providing meaningful information on patients with different defects in oxidation.

In developing the method, experiments were carried out using cells suspended in phosphate buffer saline. It was found that there was a rapid decrease in the number of viable cells during the time of incubation. Less than $50 \%$ of the initial cell count were viable as tested with Trypan blue after $3 \mathrm{~h}$, and after $5 \mathrm{~h}$ there were less than $10 \%$ viable cells. It was for this reason that the method was developed in which experiments were performed on monolayers. The special Leibovitz's L-15 medium was chosen instead of MEM because it is not a bicarbonate containing buffer which would require acidification of the medium for the release of $\mathrm{CO}_{2}(20)$; this permits the avoidance of the volatilization of octanoic and butyric acids, which would give high and variable blank values. Furthermore, it might be expected that an absence of bicarbonate would direct the metabolism of fatty acids towards oxidation rather than to the pathway of triglyceride synthesis, which requires exogenous $\mathrm{CO}_{2}$.

The data obtained with three distinct pathologic cell lines are consistent with current knowledge of fatty acid oxidation. Long chain fatty acids mobilized from adipose tissue enter the cell and are activated to fatty acyl CoA esters by fatty acyl-CoA synthetase. Long chain fatty acyl residues are then transferred from coenzyme A to carnitine by carnitine palmitoyl transferase (CPTI) located on the outer face of the inner mitochondrial membrane. Carnitine is the obligatory carrier of long chain fatty acids across the mitochondrial membrane. Inside the mitochondria, a second carnitine palmitoyl transferase (CPT II) bound to the inner face of the inner mitochondrial membrane catalyzes the reverse reaction, reconverting fatty acyl carnitine to fatty acyl $\mathrm{CoA}$, which can then undergo $\beta$-oxidation. In contrast to the long chain fatty acids, medium and short chain fatty acids are converted to their acyl CoA derivatives inside the mitochondria so that CPT reaction is not necessary for their oxidative catabolism $(17,23,24)$.

The finding that in CPT deficiency there is a nearly complete defect in the oxidation of $\left[{ }^{14} \mathrm{C}\right]$-oleate whereas there is no defect in the oxidation of octanoate, butyrate, and succinate confirms the validity of this system for the systematic study of fatty acid oxidation. The difference between the mean production rates of $\left[{ }^{14} \mathrm{CO}_{2}\right]$ from $\left[1-{ }^{14} \mathrm{C}\right]$-oleate and $\left[\mathrm{U}_{-}{ }^{14} \mathrm{C}\right]$-oleate expressed as $\%$ of control (19\% and 5\%, respectively) is not explained. It could be due to a rate limiting step of fatty oxidation at the level of medium chain acyl CoA dehydrogenase. It needs further studies on different pathologic cell lines to obtain additional information. The mechanism of the elevated rate of oxidation of octanoate and succinate observed in these cells is not clear, but it is a reasonable hypothesis that this reflects a compensatory mechanism for the defective oxidation of long chain fatty acids caused by the primary defect.

The process of $\beta$-oxidation within the mitochondria is considered to involve four enzymes in sequence. It requires FAD and NAD as cofactors and results in the formation of acetyl CoA. Pig liver mitochondria contain three acyl CoA dehydrogenases that may be differentiated on the basis of the ranges of their acyl chain length specificity. A long chain enzyme catalyzes reaction of compounds from $C_{6}$ to $>C_{16}$; a general enzyme, from $C_{4}$ to $C_{16}$; and a short chain enzyme, from $\mathrm{C}_{4}$ to $\mathrm{C}_{6}(2)$. Information on this issue of chain length specificity in man is not available. All the FAD-dependent acyl CoA dehydrogenases, including these three and isovaleryl, methylbutyryl, isobutyryl, and glutaryl CoA dehydrogenases require two proteins in common for electron transport from the reduced acyl CoA dehydrogenases to coenzyme $Q$ in the electron transport chain: the electron transferring flavoprotein (ETF) and the iron sulfur flavoprotein (ETF dehydrogenase) $(18,33)$. In inherited glutaric aciduria type II (GAII) there appears to be a generalized defect in all the FAD-dependent acyl CoA dehydrogenases as reasoned from the pattern of the urinary organic acids $(13,31,34)$ and the demonstration of defective oxidation of leucine, isoleucine, valine, lysine, and butyrate in cultured fibroblasts $(22,31,32)$. A combined defect in so many dehydrogenases could result from a defect either in protein necessary for their activity or in a cofactor common to each $(13,31$, 32). Moreover there is some evidence that GAII is an heterogeneous disorder (8). Our observations that in a patient with severe neonatal disease and glutaric aciduria type II there was a profound defect in the oxidation of oleate, octanoate, and butyrate provides further evidence for a generalized deficiency of the oxidation of fatty acids in this condition.

Long chain fatty acids may serve as precursors of medium and short chain dicarboxylic acids (30). These dicarboxylic acid products are virtually absent from normal human urine. They are observed in the urine under conditions in which the $\beta$-oxidation systems are overloaded, as in ketotic states $(16,28)$ and various pathologic conditions $(5,10,21,27)$, after intake of medium chain triglycerides (25), or when $\beta$-oxidation is impaired as in Jamaican vomiting sickness (35), Reye syndrome (19), carnitine and CPT deficiency (9), and GAII (34). These compounds are most probably formed in the liver from long chain monocarboxylic acids by primary microsomal $\omega$-oxidation to long chain dicarboxylic acids followed by mitochondrial $\beta$-oxidation $(3,29)$.

In inherited dicarboxylic aciduria $(15,26,36)$ patients have a urinary organic acid pattern of dicarboxylic aciduria in which adipic acid $\left(\mathrm{C}_{6}\right)$, suberic acid $\left(\mathrm{C}_{8}\right)$, and sebacic acid $\left(\mathrm{C}_{10}\right)$ are excreted in large amounts along with their glycine conjugates. Short chain fatty acid excretion is not seen. The dicarboxylic aciduria is increased strikingly during fasting (36) suggesting a specific defect in fatty acid oxidation. A primary defect has been hypothesized to be localized at the long chain or general acyl CoA dehydrogenase steps but this has not yet been demonstrated (15, 26).

The finding in the cells of a patient with dicarboxylic aciduria that there is a reduction in the oxidation of $\left[\mathrm{U}-{ }^{14} \mathrm{C}\right]$-oleate and $\left[{ }^{14} \mathrm{C}\right]$-octanoate and normal oxidation of butyrate and succinate is consistent with this hypothesis. The apparently normal oxidation of $\left[1-{ }^{14} \mathrm{C}\right]$-oleate has also been observed by Naylor et al., (26), in a preliminary experiment. This suggests that at least one $\beta$-oxidation occurs normally in this condition, but only $50 \%$ of the $\left[{ }^{14} \mathrm{CO}_{2}\right]$ released by the control cells was obtained from the patient's cells when uniformly labeled oleate was used. When the data obtained in the patient with GAII were compared with those in the patient with dicarboxylic aciduria, the defect in the oxidation of $\left[\mathrm{U}-{ }^{14} \mathrm{C}\right]$-oleate and $\left[1-{ }^{14} \mathrm{C}\right]$-octanoate was significantly greater in GAII $(P<0.001$ and $<0.05$ respectively). These results are consistent with the differences in the clinical severity of the two disorders. They suggest that in dicarboxylic aciduria there is a mutation which affects the function of fatty acyl CoA dehydrogenase less profoundly; however, there is almost certainly heterogeneity in these groups of individuals particularly in glutaric aciduria type II and in inherited dicarboxylic aciduria.

Further studies on a wide variety of patients with these disorders should provide additional information on the molecular defect and help to elucidate the question of acyl chain length specificity of the human fatty acyl CoA dehydrogenases. 


\section{REFERENCES AND NOTES}

1. Bank, W. J., DiMauro, S., Bonilla, E., Capuzzi, D. M., and Rowland, L. P.: A disorder of muscle lipid metabolism and myoglobinuria: Absence of carnitine palmitoyltransferase. N. Engl. J. Med., 292: 443 (1975).

2. Beinert, H.: Acyl CoA dehydrogenases. In: P. D. Boyer, H. Lardy, and K. Myrback: The Enzymes Vol. 7 p. 447 (Academic Press, New York, 1963).

3. Bjorkhem, I.: On the mechanism of regulation of $\omega$ oxidation of fatty acids. J. Biol. Chem., 25I: 5259 (1976).

4. Bougneres, P. F., Saudubray, J. M., Marsac, C., Bernard, O., Odievre, M., and Girard, J.: Fasting hypoglycemia resulting from hepatic carnitine palmitoyl transferase deficiency. J. Pediatr., 98: 742 (1981).

5. Chalmers, R. A. and Lawson, A. M.: Dicarboxylic aciduria as an indicator of defective $\beta$-oxidation in twin siblings with a vomiting sickness and hypoglycemia similar to Jamaican vomiting sickness. Biochem. Soc. Trans. 6: 111 (1978)

6. Cham, B. E. and Knowles, B. R.: A solvent system for delipidation of plasma or serum without protein precipitation. J. Lipid. Res., 17: 176 (1976).

7. Chapoy, P. R., Angelini, C., Brown, W. J., Stiff, J. E., Shug, A. L., and Cederbaum, S. D.: Systemic carnitine deficiency. A treatable inherited lipid storage disease presenting as Reye's syndrome. N. Engl. J. Med., 303: 1389 (1980).

8. Coudé, F. X., Ogier, H., Charpentier, C., Thomassin, G., Checoury, A., AmedeeManesne, O., Saudubray, J. M., and Frézal, $\mathbf{J}$.: Neonatal glutaric aciduria type II: an X linked recessive inherited disorder. Hum. Genet., 59: 263 (1981).

9. DiMauro, S.: Metabolic myopathies. In: P. J. Vinken, G. W. Bruyn: Handbook of Clinical Neurology (North Holland Publishing Company, Amsterdam, 1979).

10. Dosman, J., Crawhall, J. C., Klassen, G. A., Mamer, O. A., and Neumann, P.: Urinary excretion of $\mathrm{C}_{6}-\mathrm{C}_{10}$ dicarboxylic acids in glycogen storage disease types I and III. Clin. Chim. Acta., 51: 93 (1974).

11. Dusheiko, G., Kew, M. C., Joffe, B. I., Lewin, J. R., Path, F. F., Mantagos, S., and Tanaka, K.: Recurrent hypoglycemia associated with glutaric aciduria type II in an adult. N. Engl. J. Med., 301: 1405 (1979).

12. Engel, A. G. and Angelini, C.: Carnitine deficiency of human skeletal muscle with associated lipid storage myopathy: a new syndrome. Science, 173: 899 (1973).

13. Goodman, S. I., Mc Cabe, E. R. B., Fennessey, P. V., and Mace, J. W.: Multiple acyl-CoA dehydrogenase deficiency (glutaric aciduria type II) with transient hypersarcosinemia and sarcosinuria; possible inherited deficiency of an electron transfer flavoprotein. Pediatr. Res., 14: 12 (1980).

14. Gregersen, N., Lauritzen, R., and Rasmussen, K.: Suberylglycine excretion in the urine from a patient with dicarboxylic aciduria. Clin. Chim. Acta, 70: 417 (1976).

15. Gregersen, N., Rosleff, F., Kolvraa, S., Hobolth, N., Rasmussen, K., and Lauritzen, R.: Non-ketotic $\mathrm{C}_{6}-\mathrm{C}_{10}$ dicarboxylic aciduria: biochemical investigations of two cases. Clin. Chim. Acta, 102: 179 (1980).

16. Greter, J., Lindstedt, S., Seeman, H., and Steen, G.: 3-Hydroxydecanedioic acid and related homologues: urinary metabolites in ketoacidosis. Clin. Chem. 26: $261(1980)$

17. Groot, P. H. E., Scholte, H. R., and Hulsmann, W. C.: Fatty acid activation. Specificity, localization and function. Advan. Lipid. Res., 14: 75 (1976).

18. Hall, C. L.: Acyl-CoA dehydrogenases and electron-transferring flavoprotein. Methods Enzymol., 53: 502 (1978)

19. Harrington, W., Liu, A. S., Lonsdale, D., and Igou, D.: Urinary organic acid profiles of Reye's syndrome patients. Clin. Chim. Acta, 74: 247 (1977)
20. Leibovitz, A.: The growth and maintenance of tissue-cell cultures in free gas exchange with the atmosphere. Am. J. Hyg., 78: 173 (1963).

21. Lindstedt, S., Norberg, K., Steen, G., and Wahl, E.: Structure of some aliphatic dicarboxylic acids found in the urine of an infant with congenital lactic acidosis. Clin. Chem., 22: 1330 (1976).

22. Mantagos, S., Genel, M., and Tanaka, K.: Ethylmalonic-adipic aciduria. In vivo and in vitro studies indicating deficiency of activities of multiple acyl-CoA dehydrogenases. J. Clin. Invest., 64: 1580 (1979).

23. McGarry, J. D., Leatherman, G. F., and Foster, D. W.: Carnitine palmitoyl transferase $I$. The site of inhibition of hepatic fatty acid oxidation by malonyl CoA. J. Biol. Chem., 253: 4128 (1978).

24. McGarry, J. D. and Foster, D. W.: Regulation of hepatic fatty acid oxidation and ketone body production. Ann. Rev. Biochem., 49: 395 (1980).

25. Mortensen, P. B. and Gregersen, N.: Medium-chain triglyceride medication as a pitfall in the diagnosis of non-ketotic $\mathrm{C}_{6}-\mathrm{C}_{10}$ dicarboxylic acidurias. Clin. Chim. Acta, 103: 33 (1980).

26. Naylor, E. W., Mosovich, L. L., Guthrie, R., Evans, J. E., and Tieckelmann, H.: Intermittent non-ketotic dicarboxylic aciduria in two siblings with hypoglycemia: an apparent defect in $\beta$-oxidation of fatty acids. J. Inher, Metab. Dis., 3: 19 (1980).

27. Niwa, T., Ohki, T., Maeda, K., Saito, A., and Kobayashi, K.: Pattern of aliphatic dicarboxylic acids in uremic serum including a new organic acid, 2,4-dimethyladipic acid. Clin. Chim. Acta, 99: 71 (1979).

28. Pettersen, J. E., Jellum, E., and Eldjarn, L.: The occurence of adipic and suberic acid in urine from ketotic patients. Clin. Chim. Acta, 38: 17 (1972).

29. Pettersen, J. E.: Formation of $n$-hexanedioic acid from hexadecanoic acid by an initial $\omega$-oxidation in ketotic rats. Clin. Chim. Acta, 41: 231 (1972).

30. Pettersen, J. E. and Stokke, O.: Branched short-chain dicarboxylic acids in human urine. Biochim. Biophys. Acta, 304: 316 (1973).

31. Przyrembel, H., Wendel, U., Becker, K., Bremer, H. J., Bruinvis, L., Ketting, D., and Wadman, S. K.: Glutaric aciduria type II: report on a previously undescribed metabolic disorder. Clin. Chim. Acta, 66: 227 (1976).

32. Rhead, W., Mantagos, S., and Tanaka, K.: Glutaric aciduria type II. In vitro studies on substrate oxidation, acyl-CoA dehydrogenases, and electron-transferring flavoprotein in cultured skin fibroblasts. Pediatr. Res., 14: 1339 (1980).

33. Ruzicka, F. J. and Beinert, H.: A new iron sulfur flavoprotein of the respiratory chain. J. Biol. Chem., 252: 8440 (1977).

34. Sweetman, L., Nyhan, W. L., Trauner, D. A., Merritt, T. A., and Singh, M.: Glutaric aciduria type II. J. Pediatr., 96: 1020 (1980).

35. Tanaka, K., Kean, E. A., and Johnson, B.: Jamaican vomiting sickness. N. Engl. J. Med., 295: 461 (1976).

36. Truscott, J. W., Hich, K., Pullin, C., Halpern, B., Wilcken, B., Griffiths, I., Silink, M., Kilham, H., and Grunseit, F.: Dicarboxylic aciduria: the response to fasting. Clin. Chim. Acta, 94: 31 (1979).

37. This research was supported by United States Public Health Service grants No HD-04608, from the National Institute of Child Health and Human Development, and No GM-17702, General Medical Sciences, National Institutes of Health, Bethesda, Maryland and by Conseil Scientifique C.H.U. Necker Enfants Malades, Paris 15, France.

38. Requests for reprints should be addressed to: Dr Jean-Marie Saudubray, Clinique de Génétique Médicale, Hôpital des Enfants Malades, 149, rue de Sèvres, 75743 Paris Cedex 15, France.

39. We thank Ocean Pellet, Margaret Smith and David Weinstein for their comments and helpful discussions, and Reine McGill for her technical assistance.

40. Received for publication September 15, 1981

41. Accepted for publication April 16, 1982 . 